\title{
Influence of Growth Rate on the Enzymes of Ammonia Assimilation in Some Members of the Genus Erwinia
}

\author{
By B. JOHNSON AND D. PULMAN \\ Department of Microbiology, The University, Newcastle upon Tyne NE1 $7 R U$
}

(Received 24 July 1978; revised 12 September 1978)

\begin{abstract}
The influence of specific growth rate on the ammonia-assimilating enzymes glutamine synthetase, NADP-linked glutamate synthase and NADP-linked glutamate dehydrogenase was studied in ammonia-limited and glucose-limited chemostat cultures of Erwinia carotovora var. carotovora, E. nigrifluens and E. amylovora. The response of these organisms, representatives of various 'enzyme groups' within the genus Erwinia, showed considerable variation and confirmed the heterogeneity of the genus with respect to ammonia-assimilating enzymes. The overall significance of the glutamine synthetase/glutamate synthase pathway in any organism where the synthesis of these enzymes is not constitutive is questioned.
\end{abstract}

\section{INTRODUCTION}

In bacteria, there are two main pathways for the incorporation of ammonia into organic acceptors (Brown et al., 1974; Brown \& Johnson, 1977): the NADP-dependent glutamate dehydrogenase (GDH), and the energy-dependent, coupled system of glutamine synthetase (GS) and NADP- (or NAD-)dependent glutamate synthase (GOGAT). Both routes result in the net synthesis of one molecule of glutamate from ammonia. The coupled system, having the highest affinity for ammonia, will operate efficiently at low ammonia concentrations, but its energy dependence is the price which must be paid for such efficiency (see Brown et al., 1974).

We reported earlier that the phytopathogenic genus Erwinia is heterogeneous with respect to the ammonia-assimilating enzymes described above (Pulman \& Johnson, 1978). Three main groups were recognized: (i) those organisms showing activity of GS, NADP-GOGAT and NADP-GDH, (ii) those organisms showing activity of GS and NADP-GOGAT and (iii) those organisms showing only GS activity. The activities of these enzymes, especially GS and GDH, showed large variations in response to medium ammonia concentrations at a fixed growth rate in chemostat cultures. Such relationships have also been shown with other bacteria (see, for example, Meers \& Tempest, 1970; Meers et al., 1970; Brown et al., 1973). The present paper reports an investigation into the influence of specific growth rate on the presence and activity of GS, GOGAT and GDH in ammonia-limited and ammoniaexcess chemostat cultures of representatives of each of the three enzyme groups described above. The study was undertaken in the belief that such an approach would not only shed light on mechanisms of ammonia assimilation in Erwinia spp., but might also give a further insight into the general physiological significance of the GS/GOGAT and GDH routes of ammonia assimilation. 


\section{METHODS}

Bacteria and their growth. The strains of $E$. amylovora, E. carotovora var. carotovora and E. nigrifluens and their maintenance were described previously (Pulman \& Johnson, 1978). They were grown in a Portontype chemostat under ammonia-limited and ammonia-excess (glucose-limited) conditions as described by Pulman \& Johnson (1978).

Analyses. The preparation of cell-free extracts and assays of GS, GOGAT, GDH and protein were as described previously (Pulman \& Johnson, 1978). The ammonia content of spent media was determined by the method of Fawcett \& Scott (1960), and glucose was assayed with a Boehringer glucose oxidase test kit.

\section{RESULTS}

The influence of specific growth rate (in the range 0.05 to $0.26 \mathrm{~h}^{-1}$ ) on the activities of GS, NADP-GOGAT and NADP-GDH in ammonia-limited and glucose-limited chemostat cultures of $E$. carotovora var. carotovora, E. nigrifluens and E. amylovora were investigated.

In $E$. carotovora var. carotovora, all three enzymes were detected under all cultural conditions tested. In ammonia-limited cultures (Fig. 1a), GS activities were high, and decreased in response to increased growth rate; the pattern of NADP-GOGAT activity closely mirrored that of GS. However, the most dramatic feature observed was the linear increase in NADP-GDH activity in response to increased growth rate. In glucose-limited cultures (Fig. 1b), GS and NADP-GOGAT activities were always low, whereas NADPGDH again increased linearly in response to increased growth rate, although the GDH activities of glucose-limited cultures were generally lower than those of equivalent ammonialimited cultures, except at the lowest growth rate tested $\left(0.05 \mathrm{~h}^{-1}\right)$.

In $E$. nigrifluens, which was unable to maintain a growth rate of $0.19 \mathrm{~h}^{-1}$ or higher, only GS and NADP-GOGAT were detected under the growth conditions employed (Table 1). Under both ammonia-limited and glucose-limited conditions, the pattern of response of both enzymes to increased growth rate was similar to that observed in $E$. carotovora var. carotovora.

In E. amylovora, only GS was detected under all growth conditions tested (Table 1). The activity of the enzyme was high in ammonia-limited cultures and decreased with increasing growth rate. In glucose-limited cultures, GS activities were consistently low, and increasing the growth rate had little effect compared with that under ammonia-limited conditions.

\section{DISCUSSION}

When the growth rate of a chemostat culture is increased, the bacteria must increase their rate of cellular biosynthesis. With respect to ammonia-assimilating enzymes, either (i) amounts sufficient to satisfy growth at the fastest rate must be synthesized over the full range of growth rate or (ii) increased synthesis should be observed in response to increased growth rate. From the point of view of metabolic economy, the latter seems more likely.

In $E$. carotovora var. carotovora, such a response to growth rate was clearly seen with a linear increase in NADP-GDH activity under both ammonia-limited and glucose-limited conditions. This behaviour corresponds closely to that described in Escherichia coli $\mathrm{W}$ by Senior (1975), who suggested that the size of the intracellular pool of 2-oxoglutarate might control the rate of synthesis of GDH. In the present study, the activities of GDH were greater in ammonia-limited cultures than in corresponding glucose-limited cultures; it might be expected, therefore, that pool levels of 2-oxoglutarate would be larger in the former than the latter. There appeared to be no direct relationship between GS and GDH activities in $E$. carotovora var. carotovora, thus apparently precluding any regulatory interaction of the type proposed in Klebsiella aerogenes (Magasanik et al., 1973), although a relationship betweeen GS and GOGAT activities is possible. In E. carotovora var. carotovora, 


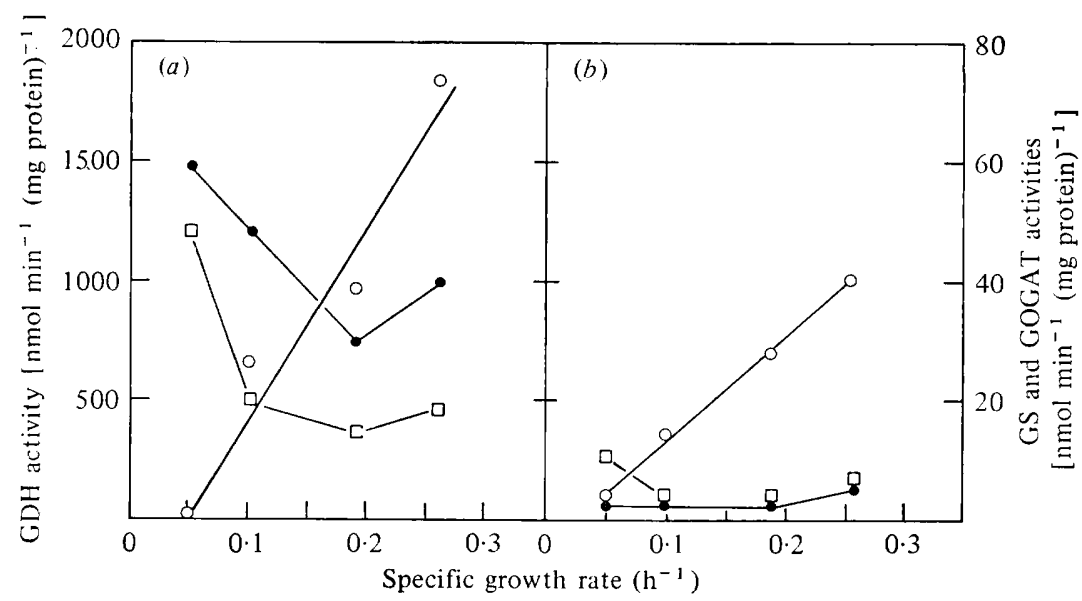

Fig. 1. Influence of growth rate on the specific activities of GS (๑), NADP-GOGAT ( $\square$ ) and NADP-GDH $(O)$ in ammonia-limited $(a)$ and glucose-limited $(b)$ chemostat cultures of $E$. carotovora var. carotovora $\left(30^{\circ} \mathrm{C}, \mathrm{pH} 6 \cdot 8\right)$.

Table 1. Influence of growth rate on the specific activities of ammonia-assimilating enzymes in chemostat cultures of E. nigrifluens and E. amylovora $\left(30^{\circ} \mathrm{C}, \mathrm{pH} 6 \cdot 8\right)$

\begin{tabular}{|c|c|c|c|c|}
\hline \multirow{3}{*}{$\begin{array}{l}\text { Growth } \\
\text { limiting } \\
\text { substrate }\end{array}$} & \multirow{3}{*}{$\begin{array}{l}\text { Specific } \\
\text { growth rate } \\
\left(\mathrm{h}^{-1}\right)\end{array}$} & \multicolumn{3}{|c|}{ 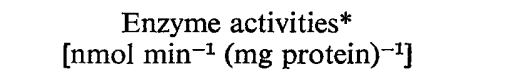 } \\
\hline & & \multicolumn{2}{|c|}{ E. nigrifluens } & E. amylovora \\
\hline & & GS & NADP-GOGAT & GS \\
\hline Ammonia & $\begin{array}{l}0.05 \\
0 \cdot 10 \\
0 \cdot 19 \\
0 \cdot 26\end{array}$ & $\begin{array}{l}92 \\
50 \\
W \\
W\end{array}$ & $\begin{array}{l}41 \\
38 \\
W \\
W\end{array}$ & $\begin{array}{l}92 \\
34 \\
32 \\
29\end{array}$ \\
\hline Glucose & $\begin{array}{l}0.05 \\
0 \cdot 10 \\
0 \cdot 19 \\
0 \cdot 26\end{array}$ & $\begin{array}{r}3 \\
5 \\
W \\
W\end{array}$ & $\begin{array}{r}24 \\
4 \\
W \\
W\end{array}$ & $\begin{array}{r}11 \\
10 \\
15 \\
5\end{array}$ \\
\hline
\end{tabular}

W, Washout occurred.

* NADP-GDH activity in both cultures and NADP-GOGAT activity in E. amylovora cultures were not detected, i.e. $<1 \mathrm{nmol} \mathrm{min}^{-1}(\mathrm{mg} \text { protein })^{-1}$.

NADP-GDH is the major ammonia-assimilating route under most growth conditions, the importance of the GS/GOGAT couple being restricted to low growth rates $\left(<0 \cdot 10 \mathrm{~h}^{-1}\right)$ under ammonia-limited conditions. Indeed, in any organism possessing an ammoniarepressible GS, it would seem that this pathway could only be of significance under (i) ammonia-limited conditions or (ii) ammonia-excess conditions at very low growth rates.

In E. nigrifluens, which possesses GS and GOGAT activities only, the general pattern of change in these enzymes was similar to that in $E$. carotovora var. carotovora, although $E$. nigrifluens was unable to grow at rates of $0 \cdot 19 \mathrm{~h}^{-1}$ and above. The activities of GS and GOGAT in ammonia-limited cultures were probably sufficient to account for ammonia assimilation at the observed growth rates. However, under glucose-limited conditions this was not the case (GS activity was too low), implying that ammonia assimilation must have taken place via some other route.

In E. amylovora, only GS activity was detectable, and the enzyme showed a similar response to medium ammonia concentration and growth rate to that observed in $E$. carotovora var. carotovora. These findings clearly support the earlier suggestion (Pulman \& 
Johnson, 1978) that an as yet undiscovered pathway of ammonia assimilation operates in this organism. Further, in view of the decrease in GS activity resulting from an increase in medium ammonia availability and in growth rate, it would seem unlikely that the portal for ammonia assimilation could involve GS linked to an amide-transfer enzyme, i.e. analogous to GS/GOGAT.

The present study has confirmed the heterogeneity of the genus Erwinia with respect to ammonia-assimilating enzymes and has shown that for an individual organism the presence (as opposed to activity) of such enzymes is not a function of growth rate. Further, in some species, at least, the known pathways of ammonia assimilation are not able to account for the observed growth. The investigation has brought into question the overall physiological significance of the GS/GOGAT pathway in any organism where the synthesis of these enzymes (especially GS) is not constitutive.

One of us (D.P.) is grateful to the Science Research Council for the award of a postgraduate studentship.

\section{REFERENCES}

Brown, C. M. \& Johnson, B. (1977). Inorganic nitrogen assimilation in aquatic micro-organisms. In Advances in Aquatic Microbiology, vol. 1, pp. 49-114. Edited by M. R. Droop \& H. W. Jannasch. London: Academic Press.

Brown, C. M., Macdonald-Brown, D.S. \& MeERS, J. L. (1974). Physiological aspects of microbial inorganic nitrogen metabolism. $A d$ vances in Microbial Physiology 11, 1-52.

Brown, C. M., Macdonald-Brown, D.S. \& Stanley, S. O. (1973). The mechanisms of nitrogen assimilation in pseudomonads. Antonie van Leeuwenhoek 39, 89-98.

FAwCETT, J. K. \& ScotT, J. E. (1960). A rapid and precise method for the determination of urea. Journal of Clinical Pathology 13, 156-159.

Magasanik, B., Prival, M. J. \& Brenchley, J. E. (1973). Glutamine synthetase, regulator of the synthesis of glutamate forming enzymes. In The Enzymes of Glutamine Metabolism, pp. 65-70.
Edited by S. Prusiner \& E. R. Stadtman. New York: Academic Press.

MeERs, J. L. \& Tempest, D. W. (1970). Regulation of glutamine synthetase synthesis in some Gramnegative bacteria. Biochemical Journal 119, 603605.

Meers, J. L., Tempest, D. W. \& Brown, C. M. (1970). 'Glutamine(amide): 2-oxoglutarate amino transferase oxido-reductase (NADP)', an enzyme involved in the synthesis of glutamate by some bacteria. Journal of General Microbiology 64, 187194.

Pulman, D. \& Johnson, B. (1978). The enzymes of ammonia assimilation and their control in members of the genus Erwinia. Journal of General Microbiology 106, 137-143.

SENIOR, P. J. (1975). Regulation of nitrogen metabolism in Escherichia coli and Klebsiella aerogenes: studies with the continuous culture technique. Journal of Bacteriology 123, 407-418. 